\title{
If We Are Too Small to See or You Have Forgotten: A postcolonial response to modern representations of the San in Alexander McCall Smith's No. 1 Ladies' Detective Agency series
}

\author{
Roie Thomas ${ }^{1}$, \\ Australian Catholic University \\ Australia
}

\begin{abstract}
Alexander McCall Smith's enormously popular fiction series set in Botswana (2000-11) appears on superficial analysis to represent the San people benignly, even affectionately. Neil Graves (2010) submits that The No.1 Ladies' Detective Agency achieves an image of "untainted and uncorrupted" Botswana through a "three-stage process of engagement, disarmament and dismissal, leaving behind a saccharine utopian Western fantasy of primitive primordial Africa" (15). However, deconstruction via a postcolonial lens shows the depictions in this text to be insidiously harmful in the light of the San's social and political disenfranchisement in Botswana since independence. Six tropes from David Spurr's seminal work The Rhetoric of Empire (1993) are deployed to position the various representations of the San children in this series firmly within a postcolonial critique, since such classifications clearly define the particular nuances and levels of the characters' literary depictions.
\end{abstract}

A recent compilation by Lonely Planet Publications (2010) which devotes a glossy doublepage spread to every country on earth, lists at the head of its Botswana section the mandatory consumption for tourists prior to visiting Botswana, namely the 1980 film The Gods Must Be Crazy and the BBC mini-series The No. 1 Ladies' Detective Agency (59). Both film and fiction series have generated substantial fascination with - and tourism to Botswana. John McAllister (2010) asserts that The No.1 Ladies' Detective Agency series is "being used by marketers to promote safari tourism" (6) and recounts his personal experience of "living on Zebra Way in Gaborone and sometimes seeing groups of tourists combing the street in search of Precious Ramotswe's house in Zebra Drive" (7).

\footnotetext{
1 rthomas@stpatricks.tas.edu.au
} 
Postcolonial readings show that, still today, many of the same colonialist premises exist to the advantage of those in power, and by extension, to the disadvantage of any others, effecting a neo-colonialist power-dynamic. This calls up Vijay Mishra and Bob Hodge's recognition (2005) that it is important for postcolonialism to be astutely aware that bourgeois anticolonial nationalism is merely another form of colonialism, effecting, as they cite Fanon (1990), "neocolonial class consolidation [which does not bring about] fundamental transformation [but rather] a mere restructuring of the social order" (384), which, I posit, is precisely the case in Botswana as regards ethnic minorities such as the San. According to David Spurr, whose work provides the theoretical framework for this analysis, even into the 1980s, the modern media still holds an "element of colonial discourse which continually returns to an idealization of the colonialist enterprise". Again, writing is implicated; various groups of peoples have become viewed as "others," in part because they have been portrayed in particular ways. (2)

Although the San won a celebrated high court battle to win back traditional hunting rights in the Central Kalahari Game Reserve (CKGR) in 2006, the cattle owners and large-scale farmers often ignore this and brutally threaten the San who exercise this right. There are welldocumented cases within Botswana itself that wells have been filled with sand or concreted over so that the San cannot access water when out hunting (Survival International 2001:2). Indeed, in December, 2006, a press statement for the CKGR NGO coalition cited the High Court ruling in favour of the government that effectively evicted the San from the CKGR by ruling it "neither unlawful nor unconstitutional" for termination of basic and essential services (health, food and water) to occur, even though the Court also ruled that "the residents had lawfully occupied the land and were unlawfully deprived of it [from 2002 onwards] it was [also] unlawful and unconstitutional to deny residents entry into the CKGR" (1).

Kuela Kiema (2010) recalls that in the past "All the government officials ... bought bundles of digwapa (biltong) from us ... We were encouraged to hunt for cash and not for the pot. Then they told us that we weren't 'pure' because we were using modern hunting techniques and that we were now posing a threat to wildlife" (83). Then, following relocation of the San out of the CKGR the San were and are incentivized to stay relocated, including encouraging people to cultivate land, a practice that, as Lekoa (2007) discovers in her research, does not sit naturally with them. Kiema continues, "The government paid people to teach our children. Locals were employed to work at the school as cooks and grounds keepers ... The local government hired people to construct the Ghantzi/Xade road. Ghantzi Craft and Botswana craft bought out handicrafts ... Tourists brought more income to the area" (Kiema 2010: 83).

The Republic of Botswana has a justified international reputation as the most peaceful nation in Africa. But a consciously designed nationalist image, with its inclusive rhetoric has, to an extent contributed to the disadvantage of minority groups through its assimilationist model, 
typical of colonial regimes and its legacy in postcolonial systems. The Tswana (the dominant ethnic group of Botswana) have the pre-eminent place in society, and minority languages like those of the San are subject to language genocide in favour of the principal tongue, Setswana (Kiema 2010: 40).

To an extent, naturally, such marginalization is the result of education, or lack thereof. Although official policy dictates that all children have the right to go to school in Botswana, the infrastructure and the nature of the San's lives mean that the poor and disenfranchised minorities rarely see this become reality. There is also no follow-up for school inattendance. So, in the case of the San, education is still elusive, with few children attending school and a desperately low literacy rate since mother-tongue education is only afforded lip-service in most schools (Mokibelo 2010). Consequently, the people are disenfranchised and generally at the mercy of aid organizations and the meagre offerings of the tourist industry where they are adopted as 'the little brown men' ... a kind of mascot embodying the timeless values of a lost world" (Lee 1986: 91) or socially entrapped as managers for Tswana cattle owners.

At present, those San who are not employed by the tourist industry are to be found manning the cattle posts of affluent Batswana as the following statement from Kiema (2010) endorses, "They looked after cattle for little or no pay. They worked under appalling conditions. No one cared how much they were paid. There were no labour laws to protect the interests of people who were now working on what was once their tribal territories" (79). Moagisi Mogalakwe, until recently administrative director the Research Centre for San Studies (pers. comm. September 2010) also notes the practice of South African hunters who, subject to game quotas, unscrupulously use San to poach for them in the CKGR, so that the San effectively take on all the attendant risks that this involves.

\section{Theoretical framework}

My main reason for using Spurr's categories as the analytical enframing is that it is robust and comprehensive, most specifically in its identification and detailed analysis of the modes of colonialist assumptions and practices. Also, those very structures along the spectrum of colonialist rhetoric identified by Spurr naturally overlap and serve as an organizational metaphor for the inherent heterogeneity of cultures, often dismissed in a colonialist mindset in favour of convenient, essentializing, monolithic generalizations. Six of the twelve tropes identified by Spurr are, as I demonstrate, epitomised within the McCall Smith series: Appropriation, Aestheticization, Debasement, Negation, Affirmation and Idealization. Each will be defined most effectively by way of their manifestations in the narratives. * 
My postcolonialist deconstruction of McCall Smith's literary text, omnipresent in Botswana tourist outlets as well as being popular in Britain and her old colonies, is carried out in the spirit of P.W. Mwikisa's (2006) discourse analysis of a text also ubiquitous in tourist outlets in Botswana, namely Bessie Head's 1971 novel, Maru. Mwikisa's analysis asserts that "Maru powerfully contests [the corralling of San] into exclusive reserves where they would, supposedly be happy to practise their stone-age hunting and gathering lifestyle but at the same time remain available to the scientific scrutiny of the modern world" (93). McCall Smith's narrative features two San orphans fostered by the main character, Precious Ramotswe and her husband Mr J.L.B. Matekoni, who are Tswana, members of the dominant ethnic group in Botswana. Before the narrative opens, the two San children were discovered alone in the Kalahari, much like Head's central character, a Masarwa (Botswana San) orphan girl adopted and named by a white missionary, which, as Mwikisa asserts is an attempt to "register and insert the voice of Basarwa in Botswana's monophonous national discourse" (92).

* All references to Spurr's tropes will be capitalized throughout this article so as to distinguish their conceptually postcolonial usage from more general interpretations of the terms.

McCall Smith apparently feels no such obligation to deviate from the monophony. Indeed, as McAllister (2010) claims, "[he] seems to buy into these simplifications ... [publicly bemoaning negative representations of Africa as forgetting] ' $[\mathrm{t}]$ he laughter. The kindness. The beauty'" (3). The San children in McCall Smith's series, much as they are loved, are always defined by their assimilation into Tswana culture. Having been buried up to their necks in the sand by their dying mother the children are discovered and rescued. The mother's act, incidentally, is an ancient San survival practice, also alluded to in The Gods Must Be Crazy where Mpudi recounts "I fled, deep into the Kalahari. I died you know. Dehydration. Some of those little buggers found me, and they buried me. Only my head stuck out". Before McCall Smith's narrative introduces them, the children had been taken to an orphan farm, and from there fostered by the protagonists.

In this series, McCall Smith is, I suggest, guilty of the less overtly objectionable tropes of Spurr's spectrum in his depiction of the San. When the children first come to live with the protagonists, the maid expresses an attitude of Debasement towards the race, purportedly typical among the dominant Batswana, and certainly there is no narrative sympathy for this position: "The maid's eyes widened ... Masarwa children being brought into an ordinary person's house ... was something no self-respecting person would do. These people were thieves ... Mr J.L.B. Matekoni may be trying to be kind, but there were limits to charity" (McCall Smith 2000: 99). 
This attitude of Debasement alongside Tswana Affirmation of their own superiority is centuries old, and Mwikisa cites Bessie Head's recognition of San subalternality: "It is argued that [the San] had been conquered by the more powerful Botswana tribes and from then onwards assumed the traditional role of slaves [and] are also abhorrent to Batswana because they hardly looked African but Chinese (in Mwikisa 2006: 92).

The adoption of two San children by Mma Ramotswe and her husband could be read as substitutes for Mma Ramotswe's lost baby of years before, filling her childless void, (even the two-for one can possibly be interpreted as a statement). The adoption is seen by several of the protagonists' peers to be misguidedly altruistic, the premise being that the San children will only cause problems. The Appropriation of the children by members the dominant culture for their own ends, couched in well-meaning rhetoric, rather than any attempt to return them to their own culture, is written up as only natural. The omission of such a return as a possibility suggests the San are not fit custodians of their own kind and calls up the justifications for the 'stolen generations' in Australia. The dynamic operating between the protagonists of this fiction series and the San children is a metaphor for Botswana's positioning of the San (among other minorities) whereby "Dominant elites extract material taxes in the form of labor, [etc] in addition to extracting symbolic taxes in the form of deference, demeanour, ... and acts of humility ... every public act of appropriation is, figuratively, a ritual of subordination" (Scott 1990: 188).

Mma Ramotswe demonstrates Spurr's identified attitude of Affirmation in every novel of this series as she 'sings the praises' of former President Sir Seretse Khama (deceased), the architect of modern Botswana and a member of the clan that dominated in the land long before British colonization. Precious has a photo of him on her mantlepiece in Zebra Drive, alongside one of her beloved late father and the Queen of England. This assembled triptych is an Affirmation, apparently unquestioned, of the (paternal and imperialist) place of the Tswana culture (a marriage literally personified by the current President Ian Khama, offspring of Sir Seretse Khama and an English mother); a symbolic assumption of its 'right to rule', as well as the affection with which the departed colonial establishment is still viewed by the dominant culture.

McAllister (2010) lists the "governing virtues of Precious Ramotswe's world neighbourliness, courtesy, trust, family, loyalty, and individual courage" as being the virtues of ... mid-twentieth century small-town Britain or America" (6). Such is the fondness the readership of this fiction series (and viewers of the spin-off television production) has for the central character with her homespun wisdom and traditional build, it is to be assumed that the narrative sympathy also extends to her attitude towards the Khama assimilationist policy and hegemonic place of the Tswana, much as Precious would never articulate her views in such terms 
There was her ornamental plate with its picture of Sir Seretse Khama - a prize possession ... and there was her Queen Elizabeth II teacup, with its picture of the Queen looking out in such a dignified way ... it reminded her of her duty and of the traditional values ... Not once had Seretse Khama faltered in his duty, nor had the Queen, who admired the Khama family and had always had a feeling for Africa ... and that made Mma Ramotswe feel proud of being a Motswana, and of all that Seretse and his wife had done (McCall Smith 2004: 14).

In contrast, a San take on the Queen's role in their standing as citizens of Botswana is poignantly expressed in this letter from Komtsha Komtsha,

\section{Dear Queen}

I am an old man. I am a Bushman. If we are too small to see or you have forgotten, you must ask other people what a Bushman is and where they live ... Not very long ago you gave the Tswana people their land. At that time, when you came here, what did you see? Were there only trees and black people here? Is that why you did not talk to us? The Tswana people think that you have given us to them. They do not understand that you did not see us and that it is a mistake (in Le Roux and White 2004: 182).

The San narrative on British custodianship and its postcolonial replacement is revealing and notably not even alluded to within the McCall Smith series. Kuela Kiema (2010) elucidates the feelings of his people in independent Botswana,

Our oppression and land dispossession are colonial legacies which have been institutionalised by the Botswana government ... Botswana's political independence was hell for us. The residents of CKGR began to sense trouble soon after the Botswana government came to power in 1966 ... the government started harassing us in our own land. Our parents were jailed for being on their tribal hunting grounds (81-82).

Motholeli, the older child adopted by Precious Ramotswe, is an excellent student who, despite being wheelchair-bound, is determined to be a mechanic and watches closely while her foster father works on cars, asking questions, helping out. Her disability can be read as a metaphor for her race's disenfranchisement, yet this girl makes the most of the slightest opportunity and 
the narrative suggests she will thrive as a citizen of Botswana. Mma Ramotswe stresses the importance of education in this quest and Motholeli empowers herself, within the context of the dominant culture. Indeed, as the Matron from the orphan farm says to Precious Ramotswe:

It is very kind of you to adopt them like that [... it is] such good news [that Motholeli wants to be a mechanic]. Why can't a girl become a mechanic? Even if she is in a wheelchair ... She will be able to help Mr J.L.B.Matekoni fix our pump ...[to which Precious replies] He is going to make a ramp for her wheelchair ... Then she will be able to get at the engines (McCall Smith 2002: 143).

Analysis of the discourse can read Motholeli's wheelchair ramp as the external assistance provided for assimilation to occur. This is in keeping with metaphor commonly found within disability and feminist theories and extrapolating from this is the broader position of 'disability' of the San in Botswana today, with its own set of special resources: "Disabled are perceived as unproductive members of society. Yet most disabled people are placed in a double-bind: they have access to inadequate resources because they are unemployed or underemployed, [or vice versa]" (Wendell 1996: 110). Later in the series, Mr J.L.B.Matekoni hears of a miracle cure for afflictions such as Motholeli's and takes out a loan for the treatment, for which they must drive to Johannesburg. It is difficult to be critical of such selfsacrifice and in a glorious revelation Mma Ramotswe informs her husband that there is no need for a loan, she had sold some of her cattle. But this renders Motholeli indebted to her foster parents for their altruism, and she says "I don't want anybody to cry for me [...] I am happy. I will carry on being happy" (McCall Smith 2009: 247).

In The No.1 Ladies' Detective Agency Appropriation is evident in the lack of sensitivity within the dominant culture towards their absolute commandeering of San land when Puso, the younger of the two fostered San children, becomes surly and willful, informing his foster parents that he hates them. The Matron at the orphanage advises that what Mr J.L.B. Matekoni should do is "take the boy out with him in his truck. Take him out to the lands, to see the cattle. Things like that" (McCall Smith 2002: 145). The Matron (and Precious Ramotswe who considers this good advice) is apparently oblivious of the fact that these same lands are those that the boy's ancestors once roamed freely and these same cattle, now owned by members of the dominant Tswana, are the reason (along with tourism, its associated big game hunting, and mining) the San have been summarily evicted. McCall Smith's moral code appears insensible to the fact of the San's eviction (to facilitate Tswana Appropriation) as is evident through Precious's thoughts as she laments the encroaching urbanization and the pace of modernization only insofar as it affects relatively privileged people like herself, 
It was a large house by modern standards, built in a day when builders had no reason to worry about space. There was the whole of Africa in those days, most of it unused, and nobody bothered to save space. Now it was different, and people had begun to worry about cities and how thy gobbled up the bush (McCall Smith 2007: 7)

Puso bitterly denies his ethnicity for a time, being bullied for it at school in Gaborone. He sobs to Mma Ramotswe: "I don't want to be ... that" (McCall Smith 2009: 38), a selfNegation based on years of systemic Negation that Bihela Sekere, a young San man relates to: "I could not touch anything that has to do with Anthropology - if I saw the word 'Bushman' or 'San' or 'Basarwa' I would just put the book aside" (5). Such a story was also related to anthropologist Sandy Gall (2001) during his interviews with displaced San: "Some of the other children beat us up and the teachers, too [because] I was depending on wild foods. They picked on me because I am Bushman ... [my sister and I] dropped out because we were discriminated against and threatened so I could not go to classes" (122), and as San author Kuela Kiema (2010) remembers with horror,

[T] he teachers said the government wanted to make us human beings and that we should stop being Basarwa. They started teaching us 'proper' human behaviour. In [our] tradition, when being called you respond by saying Yee! We had never before been told it was an insult, or inhuman ... But now we would receive corporal punishment if we responded to a teacher's call with Yee! ... We didn't know what it was called then but it was ethnocentrism of the worst kind - yet we were expected to teach our parents this 'better' culture ... Our school reports said ... Parents, this child can do better than this, but his main problem is that he does not know Setswana, please teach him Setswana at home. How could our parents teach us Setswana? (39).

Puso is constantly reminded by his foster-parents of the necessity to be proud of his heritage; they remind him of the San's ancient and unique culture, "'You could be a great tracker', Mr J.L.B.Matekoni said to him once. 'You have that gift from your people' " (McCall Smith 2009: 36). In this case, Spurr's trope of Idealization comes into play, where a group is considered no threat, so the dominant culture can afford to use glowing rhetoric about the strengths of the Other, since it is now only of historical interest - apart from situations where it is carefully contained and contrived for tourists, as the ingenuously Idealized comments of the tourists in Lekoa's 2007 documentary attest:

Tourists: They hardly suffer from funny diseases like heart attack ... because of the type of food they eat ... There is actually so much that we can learn from these people, you know. You realise that these people can stay for some time without food because they have their own traditions. And 
there is apparently great wealth of knowledge of all the different substances and their properties, poisonous, non-poisonous ... but there should be a balance between development and preserving culture.

Significantly, it was Motholeli who dug herself and her baby brother out of the hole in the sand (again, a concept heavy with imagery) and walked for miles until they were picked up and taken to the orphanage, calling up the Idealization trope again by highlighting the fact that the race has the definitive genetic blueprint for survival. But the postcolonialist again could justifiably assert that the narrative endorses a retreat out of the desert as the only way the San can survive, that their child-like status can only be realized as fully human by 'growing up' (read: urbanization, assimilation into the dominant culture, or, as Lekoa (2007: 51) dubs it "Tswanatization"). This, of course, suits the corporate interests of cattle owners and diamond companies just fine.

Aestheticization is evident Precious gazes (the concept of the 'gaze' as an indicator of power being the subject of much psycho-philosophical scrutiny) at the sleeping Puso, "She would gaze at him, at the perfection of his features - for he was an attractive child, with the honeycoloured skin of the Bushmen side of his family ... His Kalahari ancestors had bequeathed him eyes that shone with light" (McCall Smith 2009: 36).

Negation of an apparently benign manifestation is evident in McCall Smith's series and can also be read as Aestheticization by way of infantilization, since in this series the entire race could be romantically symbolized by these two children, much loved but ultimately required to conform. Although the author has Precious Ramotswe console her foster daughter when she is bullied at school with the words "Sir Seretse Khama said that every person in Botswana ... is of equal value. The same. That means you too" (McCall Smith 2002: 35), the very assumption of sameness in this context means downplaying her uniqueness as San for the purpose of survival at school. The irony of this is that the Human Genome Project has found "there is a San woman in the ancestry of each one of us, as far back as 200,000 years" (Global News Monitor 2005: 2). Kenneth Good (2008) articulates the government policy endorsed by Precious's homily: "In purportedly homogenous Botswana, Seretse Khama imposed a new identity on San as 'Remote Area Dwellers' (RADs). This emphasized geography and avoided the issues of ethnicity, though it was clear that the majority of new remote people were San" (107). Such an assimilation-or-perish agenda is being forced upon the San by the government of Seretse Khama's son, President Ian Khama: as the activist group The First People of the Kalahari (FPK) asserts: "Bushman villages have been cut off from their main sources of food and water and outsiders have been prohibited from entering [the CKGR] to provide relief ... heavy contingents of police, military and park rangers trucked out about 40 people - most of the remaining inhabitants - at gunpoint" (Global News Monitor 2005: 2). 
There is no suggestion by the adults in McCall Smith's narrative, that perhaps some facets of San culture could work their way into the curriculum, even incidentally, unless, as Bennun (2004) asserts, it is as an historical narrative of an "extinct" race. To this extent Spurr's trope of Negation is again evident, in the systemic omission or dismissal of a rich cultural knowledge system despite the fact that recognition of - and systemic accommodation for Indigenous Knowledge Systems is an acknowledged necessity in the Preamble to the World Declaration on Education for All which declares: "traditional knowledge and indigenous cultural heritage have a value and validity in their own right and a capacity to both define and promote development" (cited in Hays 2001: 239). As San men James Morris and Aron Johannes articulate in a booklet of San voices, "We do not want to cast away the importance of education today, but traditional education must become intermingled so that the essence of both can come together" (Stewart and Hays 2010: 2).

An elderly man expressed the following opinion to San author Kuela Kiema in Botswana while Kiema was a teacher-in-training, comparing the insidious process of "Tswanatization" to the Afrikaaner hubris that underscored apartheid in South Africa:

Your tax, young man, will be used to enhance the traditional customs and norms of Setswana-speaking people- but not yours ... our loyalty to the country will be measured only in your obedience to the Setswana-speaking peoples - and not to your own. These things will only lead to low self-esteem for you and your people (18-19).

Again, within the Negation trope, there is no mention of the foster children in McCall Smith's series retaining their mother-tongue and their names are Tswana names, not San, suggesting they were re-named at the orphanage. This encouragement to discard all traces of San identity is a reality for San people, as Kiema (2010) recalls clearly, "One day in 1987 Miss Susan Supang, our class teacher, wrote a list of English names for us to choose from. I chose 'Charles' (41). And, as San woman Nxisae Nxau from Tsodilo, northern Botswana, relates, such prejudice is entrenched in the Tswana culture, even when San individuals are objects of affection:

I met this man, he came up to me and said that he liked me and would want to marry me, then he asked me my name and I said "Nxisae". He said, "But what is your Tswana name, don't you have a Tswana name?" and I said, "No, I don't have." He walked away, saying, "No, I cannot fall in love with a San woman." So I said, "So?", for I am proud of my culture (in LeRoux and White 2004: 71). 
David Naude, of Shakawe, Botswana, also recounts a case of Negation, "I found out that when these other people married our women, the man would not allow the woman to speak her language, and when the children came, they were taught only to speak the language of their father ... So that is how our language is dying out (in LeRoux and White 2004: 69). Kiema substantiates such Negation, "We are still shown between the Stone Age and the Iron Age chapters" (76),

We do not feature in pre-colonial history of Botswana except as the first in habitants of southern Africa;

We do not feature in Botswana's colonial history except as expert hunters;

We do not feature in the struggle for Botswana's independence; and

We do not feature in the history of contemporary Botswana as we are still portrayed as a 'stone-age' people (75-76).

The San children's positioning within McCall Smith's fiction series is important (as is the San's positioning as children) and I argue, via a postcolonial lens, that the suggestion inherent in the text is that without Mma Ramotswe's well-meaning intercession in the children's lives (symbolic perhaps of NGO and other external intervention in the San's lives generally) they would remain disempowered, that they could never make it as self-determining citizens of Botswana. Indeed, they probably have some sense that former President Festus Mogae's insensitive and inherently racist remark, "If the Bushmen want to survive they must change, or otherwise, like the dodo, they will perish" (in Gall 2001: 84) expresses, sadly, some measure of truth.

To paraphrase Paulo Friere (1970), oppressed people are so enmeshed and have such a sense of powerlessness within the dominant society that they cannot perceive of the oppressor as being "outside themselves", consequently rendering them "fearful of freedom" and unlikely to "seek their own liberation" (128). As the aformentioned elderly man pointed out to Kuela Kiema: "Your repression has been so systematic that you are now participating in your own repression" (Kiema 2010:19). Thus, as anthropologist Jennifer Hays asserts: "Very few San individuals have been able to enter into the discourse of national and international politics as equals" (2002: 29). Indeed, Kenneth Good (2003) asserts that under the definition of 'tribe' in the Chieftancy Act the San are not recognized in the list of Botswana tribes (22). Kiema relates "At school we learned about Setswana chiefs and their taboos and totems ... No one from our tribe was in the House of Chiefs to advise parliament on matters affecting our traditions" (19). 
Suggesting that the general Tswana population (which Mma Ramotswe represents in this series) is ignorant of the San's disenfranchisement and actively believes the nationalist rhetoric of inclusiveness, Precious - with no irony - calls the San and the Tswana "the two peoples of this country" (McCall Smith 2009: 35) as though the two groups are on the same socio-economic and political levels. McCall Smith's depiction of the San children in his series as being utterly dependent upon or assimilated into the dominant culture sits comfortably and conveniently with his favoured VIP status in Botswana (Good, pers. comm. October, 2011). In The Lost World of the Kalahari (1958) Laurens van der Post mourned the "world" of the San which he had long mythologized as becoming increasingly "lost" to the Western imaginary. It is worth wondering what van der Post would make of the new manifestations of lostness the San experience today.

\section{REFERENCES}

Bennun, Neil, 2004. The Broken String: The Last Words of an Extinct People. London: Penguin.

Ditshwanelo, Botswana Centre for Human Rights, http://www.ditshwanelo.org.bw/botswana.html personal communication, Alice Mogwe, Director (18 September, 2010).

Freire, Paulo, 1970. Pedagogy of the Oppressed. Great Britain: C. Nicholls \& Co. Ltd.

Gall, Sandy, 2001. The Bushmen of Southern Africa: Slaughter of the Innocent. London: Chatto \& Windus.

Global News Monitor, Govt. denies Claims of Ethnic Cleansing Global News Monitor October 1-15, 2005. 
Good, Kenneth, 2008. Diamonds, Dispossession and Democracy in Botswana. London: Boydell \& Brewer.

Good, Kenneth, Bushmen and Diamonds: (Un)civil society in Botswana. Discussion Paper 23, Nordiska Afrikainstitutet (2003): 1-40.

Graves, Neil, 2010. The No. 1 Ladies' Detective Agency: Africa by the West and for the West, in Monaka, KC., Seda, OS., Ellece SE., and McAllister, J. (eds) Mapping Africa in the English Speaking World: Issues in Language and Literature, UK: Cambridge Scholars Publishing.

Hays, Jennifer, 2001. We can start under the trees: Mother tongue literacy and the Nyae Nyae Village Schools Project. International Literacy Conference, Cape Town, 13-17 November 2001.

Kiema, Kuela, 2010. Tears for my Land: A Social History of the Kua of the Central Kalahari Game Reserve, Tc'amnqoo. Botswana: Mmegi Publishing House.

Lee, Richard, 1986. The Gods Must Be Crazy but the State Has a Plan: Government Policies Towards the San in Namibia. Canadian Journal of African Studies, 20 (1): 91-98.

Lekoa, Dithunya S., 2007. Appropriation of Culture in Tourism: At whose benefits? Unpublished Master's thesis, Department of Social Anthropology, University of Tromsø, Norway, 2007.

Lekoa, Dithunya S., 2007. Culture on Sale (documentary film). Visual Cultural Studies, University of Troms $\emptyset$, Norway.

Le Roux, Wilhemin and White, Alison, 2004. Voices of the San, Cape Town: Kwela Books.

Lonely Planet, 2010. The Travel Book: A Journey Through Every Country in the World, $2^{\text {nd }}$ Ed., Melbourne: Lonely Planet Pty. Ltd. 
McAllister, John, 2010. Rules for Being Good: Exoticism and Nostalgia in Alexander McCall Smith's Botswana Novels" in Monaka, KC., Seda, OS., Ellece SE., and McAllister, J. (eds) Mapping Africa in the English Speaking World: Issues in Language and Literature, UK: Cambridge Scholars Publishing.

McCall Smith, Alexander, 2000. Tears of the Giraffe. Great Britain: Polygon.

McCall Smith, Alexander, 2002. The Kalahari Typing School for Men. Great Britain: Polygon.

McCall Smith, Alexander, 2003. The Full Cupboard of Life. Great Britain: Polygon.

McCall Smith, Alexander, 2004. In the Company of Cheerful Ladies. Great Britain: Polygon.

McCall Smith, Alexander, 2007. The Good Husband of Zebra Drive. Great Britain: Polygon.

McCall Smith, Alexander, 2009. The Miracle at Speedy Motors. Great Britain: Little Brown.

Mishra, Vijay \& Hodge, Bob, 2005. What was Postcolonialism? New Literary History, 36(3): 375-402.

Mogalakwe, Moagisi, 2010. Centre for San Studies, University of Botswana.

Mokibelo, Eureka, 2010. email, Centre for San Studies, University of Botswana. mokibeloeb@mopipi.ub.bw

Mwikisa, Peter, 2006. Can the Subaltern be Spoken For? Representations of Basarwa in Four Batswana Postcolonial Writers PULA: Botswana Journal of African Studies, 20(1): 86-102. 
Scott, James C., 1990. Domination and the Arts of Resistance: Hidden Transcripts. New Haven: Yale University Press.

Spurr, David, 1993. The Rhetoric of Empire: Colonial Discourse in Journalism, Travel Writing and Imperial Administration. London: Duke University Press.

Stewart, Ruth, and Hays, Jennifer (Eds.). 2010. San Voices Education: Who is Going to Drive? Botswana: Kuru Family of Organisations.

Survival International (2001) Botswana's Treatment of San Minority Provokes Demonstrations. Survival Botswana Gazette._Survival International, Press Release.

Van der Post, Laurens, 1958. The Lost World of the Kalahari. England: Penguin Books, Ltd., Wendell, Susan, 1996. The Rejected Body: Feminist Philosophical Reflections on Disability. New York: Routledge. 